\title{
PRODROMAL TRIGEMINAL SENSORY NEUROPATHY IN PROGRESSIVE SYSTEMIC SCLEROSIS
}

\author{
BY
}

\author{
P. BEIGHTON, J. M. GUMPEL, AND N. G. M. CORNES \\ Department of Medicine, St. Thomas' and Lambeth Hospitals, London
}

Neurological disturbance occurring in progressive systemic sclerosis (PSS) is rare and when seen usually takes the form of convulsions associated with hypertension and renal failure. Peripheral nerve lesions, such as are seen in other connective tissue disorders, especially in rheumatoid disease and polyarteritis nodosa, are extremely uncommon. Isolated cranial nerve lesions do not appear to have been recorded in PSS and we report this case which presented with bilateral sensory trigeminal neuropathy.

\section{Case Report}

A 66-year-old white female was referred to the Neurological Clinic at St. Thomas' Hospital in October, 1966, for investigation of sensory changes on both sides of the face, noted some time after an uneventful cholecystectomy for gallstones earlier in the year. She was found to have blunting of sensation to pin-prick over an area corresponding to the second divisions of both trigeminal nerves. The corneal reflexes were intact, and no other abnormality was noted.

Over the ensuing months, there was a progressive loss of appreciation of all modalities of sensation in the areas of all three divisions of the trigeminal nerve on both sides of the face. At the same time she became conscious of a gritty sensation in the mucous membranes of the cheeks and gums. There was no lack of salivation. Concurrently, she described the onset of Raynaud's phenomenon in the hands and feet, a polyarthritis involving elbows, wrists, and proximal interphalangeal joints of the hands, weight loss of 5 stone, and general muscle weakness most marked in the neck and shoulder girdle. During this period, the skin of the chest, forearms, and hands became thickened and stiff, and she also developed severe dysphagia and some degree of constipation.

In April, 1967, she was admitted to the Lambeth Hospital.

Physical Examination.-She was a thin woman with evidence of marked weight loss. The skin of her hands, forearms, and chest was thickened and bound down to the underlying tissues. The skin of the face was comparatively spared. There was nail-bed telangiectasia, but no evidence of vasculitis. The muscles of both limb girdles and the neck were considerably weakened, without tenderness. Both submandibular glands were enlarged.

There was complete absence of sensation in the areas of all three divisions of the trigeminal nerve bilaterally, to touch, pain, and temperature. Both corneal reflexes were absent. There was a disturbance of taste discrimination on the anterior two-thirds of the tongue and loss of sensation in the buccal mucosa.

Other systems were normal, as was urine analysis.

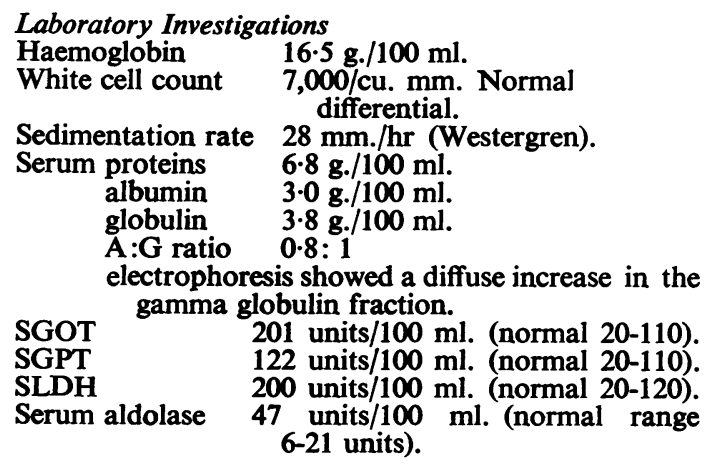

Electrocardiogram: Left bundle branch block and multiple ventricular ectopic beats.

Waaler Rose test and three L.E.-cell preparations negative.

Immuno-fluorescent studies (Dr. E. J. Holborrow): Strong antinuclear antibody at a dilution of 1 in 10 , but no thyroid or gastric antibodies.

Muscle biopsy: Lymphocytic and plasma cell infiltration with degenerative changes typical of chronic interstitial myositis.

Electromyography: Evidence of polymyositis in the right deltoid and in the muscles sampled in the right forearm. No 
evidence of a lower motor neuron lesion or myositis in the right temporalis muscle.

Barium swallow with cineradiography: Absent peristalsis in the lower two-thirds of the oesophagus consistent with systemic sclerosis.

Skin biopsy:

Thickening of the dermis with hypertrophied closely packed and hyalinized collagen bundles. Sweat glands atrophied and surrounded by dense collagenous tissue.

Buccal mucosa: Epithelium was thickened with marked acanthosis.

Submandibular gland biopsy:

Lymphocytic and plasma cell infiltration with interstitial fibrosis.

Mantoux test:

\section{1: 1,000 positive.}

The following investigations were negative or within normal limits:



\section{Discussion}

The presentation of PSS as a neurological problem is extremely unusual, especially as the disease has subsequently developed in a more typical and fairly rapid fashion, with the concurrent appearance of a polymyositis corresponding to Group III in the classification of Walton and Adams (1958) as an infrequent complication of PSS.

There appear to be no reported cases of cranial nerve lesions in PSS, nor mention of similar problems in five major series, of over 1,300 cases (Farmer, Gifford, and Hines, 1960; Leinwand, Duryee, and Richter, 1954; O'Leary and Nomland, 1930; Rivelis, 1963; Tuffanelli and Winkelmann, 1961). Convulsions have been observed (Bourne, Howell, and Root, 1960) as have non-specific electroencephographic changes (Taylor and Pacella, 1949), and an increased protein content in the cerebrospinal $\square$ fluid was found by Rossier and Hegglin-Volkmann (1954). Kibler and Rose (1960) reported a patient $\overrightarrow{\vec{F}}$ with a collagen disorder most closely resembling $\stackrel{\text { ? }}{+}$ systemic sclerosis who developed a widespread sensori-motor peripheral neuropathy. A similar $\frac{\bar{c}}{\bar{c}}$ case was described by Richter (1954).

Trigeminal nerve dysfunction was reported as an isolated neurological finding in sixteen patients by Spillane and Wells (1959). Fifteen had a purely ? sensory disturbance and in four the lesion was $\overrightarrow{\vec{\omega}}$ bilateral. No systemic disease was found in twelve $\stackrel{\sigma}{\omega}$ of these patients, while one had diabetes mellitus and three were hypertensive. Pathological material was not available in any of these cases but the authors. assumed that the lesion was primarily of the intracranial part of the sensory neurones; that is of the $\sigma$ sensory root, Gasserian ganglion, and the three o divisions of the nerve. This location was supported by the loss of taste in seven of the thirteen patients $c$ in whom the mandibular division was involved. Brodie Hughes (1958) had published an account of $\overrightarrow{0}$ three similar cases, in all of whom the sensory root $\mathscr{D}$ was found at operation to be reduced to a few wisps of nerve fibre, embedded in thickened arachnoid membrane. Histological examination showed lymphocytic infiltration, degenerating nerve fibres, and a marked increase of fibrous tissue.

The documented progression of the trigeminal $\overrightarrow{\vec{P}}$ nerve lesion, initially affecting only the second $\frac{0}{3}$ division and later including all three sensory divisions, has served to locate the lesion outside the central nervous system since there are no separate central areas of the trigeminal nucleus corresponding $\bar{\alpha}$ to its three cutaneous divisions. Alternatively, it is $\frac{0}{7}$ possible that the site of the lesion is peripherally in the end organ, but there was relative sparing of the skin of the face, even at a late stage, in this patient, $₹$ and also no evidence of sclerosis was found in the $\frac{\text { o }}{2}$ biopsy taken from an insensitive area of the buccal $\rightarrow$ mucosa.

We feel that the trigeminal neuropathy in the case $\stackrel{N}{\sigma}$ described was directly related to the PSS, although N the mechanism is obscure. However, the possibility $N$ that the disturbance is a totally unrelated chance finding falling into the category described by Spillane and Wells cannot be excluded. A unilateral or even a bilateral nerve lesion could be $\stackrel{\Phi}{\oplus}$ produced by a neurinoma or Gasserian ganglion tumour, but there is no evidence of these in this patient. On a histological level a localized area of $\overrightarrow{\mathbb{D}}$ vasculitis or sclerotic involvement of the arachnoid $\frac{\rho}{\circ}$ membrane might be responsible. The simultaneous $\varrho$ presentation and concurrent progression of both the 
trigeminal neuropathy and the systemic sclerosis make it extremely likely that these are related.

\section{Summary}

The occurrence of bilateral trigeminal sensory neuropathy in a patient with progressive systemic sclerosis is described. This association has not previously been reported.

Our thanks are due to Dr. C. E. Wheaton, consultant physician of the Lambeth Hospital, for permission to publish this case, and to Dr. R. Ross Russell, consultant neurologist, and Dr. J. Everall, consultant dermatologist, for their advice.

\section{REFERENCES}

Bourne, F. M., Howell, D. A., and Root, H. S. (1960). Canad. med. Ass. J., 82, 881 (Renal and cerebral scleroderma).

Farmer, R. G., Gifford, R. W., and Hines, E. A. (1960). Circulation, 21, 1088 (Prognostic significance of Raynaud's phenomenon and other clinical characteritics of systemic scleroderma. A study of 271 cases).

Hughes, B. (1958). Proc. roy Soc. Med., 51, 529 (Chronic benign trigeminal paresis).

Kibler, R. F., and Rose, F. C. (1960). Brit. med. J., 1, 1781 (Peripheral neuropathy in the "Collagen diseases". A case of scleroderma neuropathy).

Leinwand, I., Duryee, A. W., and Richter, M. N. (1954). Ann. intern. Med., 41, 1003 (Scleroderma: based on a study of over 150 cases).

O'Leary, P. A., and Nomland, R. (1930). Amer. J. med. Sci., 180, 95 (A clinical study of 103 cases of scleroderma).

Richter, R. B. (1954). J. Neuropath. exp. Neurol., 13, 168 (Peripheral neuropathy and connective tissue disease).

Rivelis, A. L. (1963). Arch. interamer Rheum., 6, 496 (Esclerosis sistémica progresiva. Analisis de de 66 casos).

Rossier, P. H., and Hegglin-Volkmann, M. (1954). Schweiz med. Wschr., 84, 1161 (Die Sklerodermie als internmedizinisches problem).

Spillane, J. D., and Wells, C. E. C. (1959). Brain, 82, 391 (Isolated trigeminal neuropathy. A report of 16 cases).

Taylor, R. M., and Pacella, B. L. (1949). J. nerv. ment. Dis., 109, 42 (The electroencephalogram in scleroderma).

Tuffanelli, D. L., and Winkelmann, R. K. (1961). Arch. Derm. (Chicago), 84, 359 (Systemic scleroderma. A clinical study of 727 cases).

Walton, J. N., and Adams, R. D. (1958). "Polymyositis". Livingstone, Edinburgh.

Neuropathie sensitive trigéminale comme symptôme révélateur d'une sclérose disséminée progressive

\section{RÉSUMÉ}

On décrit une neuropathie sensitive trigéminale bilatérale survenant chez un malade atteint de sclérose disséminée progressive. Une telle association n'a pas été rapportée jusqu'à maintenant.
Neuropatía sensitiva trigeminal como síntoma revelador de una esclerosis diseminada progresiva

\section{Sumario}

Se describe una neuropatía sensitiva trigeminal bilateral sobreviniendo en un enfermo con esclerosis diseminada progresiva. Tal asociación no fué descrita anteriormente. 